\title{
High flow nasal cannula oxygen therapy in immunocompromised patients with acute hypoxemic respiratory failure
}

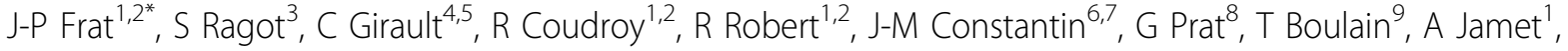 \\ A Mercat ${ }^{10}$, L Brochard ${ }^{11,12,13}$, AW Thille ${ }^{1,2}$, for the FLORALI Study Group and REVA Network
}

From ESICM LIVES 2015

Berlin, Germany. 3-7 October 2015

\section{Introduction}

In the early 2000's, two randomized controlled trials have shown that non-invasive ventilation (NIV) could decrease mortality of immunocompromised patients admitted to ICU for acute respiratory failure (ARF) as compared to standard oxygen therapy $\left(\mathrm{O}_{2}\right)[1,2]$. However, the benefits of NIV in immunocompetent patients with ARF failure are debated. High flow nasal cannula oxygen therapy (High-Flow Oxygen) may offer an alternative in hypoxemic patients. We recently found in a randomized controlled trial including 310 patients with ARF that High-Flow Oxygen decreased mortality as compared to NIV [3]. Immunocompromised patients could be also included in this study, except those with profound neutropenia. Therefore, we assessed the benefits of High-Flow Oxygen or NIV in this subgroup of patients.

\section{Objectives}

To compare intubation and mortality rates in the subset of immunocompromised patients admitted to ICU for ARF.

\section{Methods}

We performed a subgroup analysis of the FLORALI study. This study included all patients with non-hypercapnic $\left(\mathrm{PaCO}_{2} \leq 45 \mathrm{~mm} \mathrm{Hg}\right)$ ARF excluding patients with cardiogenic pulmonary edema and those with underlying chronic lung disease. Patients were assigned to three groups according to treatment: High-Flow Oxygen, $\mathrm{O}_{2}$ or NIV. The primary outcome was the intubation rate and secondary outcome included 90-day mortality. We focused on the subset of immunocompromised patients included

${ }^{1} \mathrm{CHU}$ Poitiers, Service de Réanimation Médicale, Poitiers, France Full list of author information is available at the end of the article in this study, knowing that patients with profound neutropenia were excluded.

\section{Results}

Among the 310 patients with ARF, 82 (26\%) were immunocompromised including 26 patients in the High-Flow Oxygen group, 30 in the $\mathrm{O}_{2}$ group, and 26 in the NIV group. Intubation rates were $31 \%, 43 \%$ and $55 \%$ in the High-Flow Oxygen, $\mathrm{O}_{2}$ and NIV groups, respectively $(\mathrm{p}=0.04)$. The 90 -day mortality rates were $15 \%, 27 \%$ and $46 \%$ in the High-Flow Oxygen, $\mathrm{O}_{2}$ and NIV groups $(p=0.046)$. Ventilator-free days at day 28 were $26 \pm 6,23$ \pm 10 and $14 \pm 13$ days in the High-Flow Oxygen, $\mathrm{O}_{2}$ and NIV groups, respectively $(\mathrm{p}<0.0001)$.

\section{Conclusions}

In immunocompromised patients admitted to ICU for acute hypoxemic respiratory failure, High-Flow Oxygen was associated with lower intubation and mortality rates, and a reduced duration of invasive mechanical ventilation as compared to $\mathrm{O}_{2}$ or NIV.

\footnotetext{
Authors' details

${ }^{1} \mathrm{CHU}$ Poitiers, Service de Réanimation Médicale, Poitiers, France. ${ }^{2}$ Université Poitiers, INSERM CIC 1402 (Équipe 5 ALIVE), Poitiers, France. ${ }^{3}$ Université Poitiers, INSERM CIC 1402 Biostatistics, Poitiers, France. ${ }^{4} \mathrm{CHU}$ Rouen, Service de Réanimation Médicale, Rouen, France. ${ }^{5}$ Université Rouen, UPRES EA 3830IRIB, Institute for Biomedical Research and Innovation, Rouen, France. ${ }^{6} \mathrm{CHU}$ Clermont Ferrand, Pôle de Médecine Périopératoire, Clermont-Ferrand, France. ${ }^{7}$ Université d'Auvergne, R2D2, EA-7281, Clermont-Ferrand, France. ${ }^{8} \mathrm{CHU}$ de la Cavale Blanche, Service de Réanimation Médicale, Brest, France. ${ }^{9} \mathrm{CHR}$ Orléans, Réanimation Médico-Chirurgicale, Orléans, France. ${ }^{10} \mathrm{CHU}$ Angers, Service de Réanimation Médicale et Médecine Hyperbare, Angers, France. ${ }^{11}$ St Michael's Hospital, Keenan Research Centre and Critical Care Department, Toronto, Canada. ${ }^{12}$ University of Toronto, Interdepartmental Division of Critical Care Medicine, Toronto, Canada. ${ }^{13}$ Université Créteil, INSERM UMR 955 Eq13, Créteil, France.
} 


\section{References}

1. Antonelli M, Conti G, Bufi M, Costa MG, Lappa A, Rocco M, et al: Noninvasive ventilation for treatment of acute respiratory failure in patients undergoing solid organ transplantation: a randomized trial. JAMA 2000, 283(2):235-241.

2. Hilbert G, Gruson D, Vargas F, Valentino R, Gbikpi-Benissan G, Dupon M, et al: Noninvasive ventilation in immunosuppressed patients with pulmonary infiltrates, fever, and acute respiratory failure. $N$ Engl I Med 2001, 344(7):481-487.

3. Frat JP, Thille AW, Mercat A, Girault C, Ragot S, Perbet S, et al: High-Flow Nasal Cannulae Oxygen Therapy in Acute Hypoxemic Respiratory Failure. N Engl J Med 2015, 372:2185-2196.

doi:10.1186/2197-425X-3-S1-A425

Cite this article as: Frat et al:: High flow nasal cannula oxygen therapy in immunocompromised patients with acute hypoxemic respiratory failure. Intensive Care Medicine Experimental 2015 3(Suppl 1):A425.

\section{Submit your manuscript to a SpringerOpen ${ }^{\mathcal{O}}$ journal and benefit from:}

- Convenient online submission

- Rigorous peer review

- Immediate publication on acceptance

- Open access: articles freely available online

- High visibility within the field

- Retaining the copyright to your article 